\title{
Qozloq Route (Astrabad to Shahrud) Impact on Economic Developments of the Region (Safavid Course)
}

\author{
Dr. Mustafa Nadim ${ }^{1} \&$ Ghorbanali Zahedi ${ }^{2}$ \\ ${ }^{1}$ Associate Professor, Department of History, Shiraz University, Iran \\ ${ }^{2} \mathrm{Ph}$.D. student of Islamic History of Shiraz University, Iran \\ Correspondence: Dr. Mustafa Nadim, Associate Professor, Department of History, Shiraz University, Iran. \\ E-mail: mos.nadim@gmail.com
}

Received: January 28, $2018 \quad$ Accepted: March 8, $2018 \quad$ Online Published: March 28, 2018
doi:10.5539/jpl.v11n2p6
URL: https://doi.org/10.5539/jpl.v11n2p6

\begin{abstract}
The Qozloq Route was one of the branches of the famous Silk Road in the northeast of Iran, which linked two important and strategic regions of Shahrud and Astrabad. This road constituted rough and smooth paths and was the passage of different nations with different goals. In this context, various cultures have also been published and exchanged in line with the trade of various goods.

The presence of different caravansaries around the road indicates its importance and prosperity in the Safavid course, but with all of this, there is little information available on the importance of this route in the existing travel books and historical books. Despite all the inadequacies, in this research, with the descriptive-analytical approach based on the research data, it is concluded that the Qozloq Route has been of great importance in the Safavid course, strategically, and in term of the publication of the culture and prosperity of the economy, and the dynamism of development and awareness.
\end{abstract}

Keywords: Qozloq Route, Astrabad, Shahrud, Safavid

\section{Introduction}

Roads have always played an effective and constructive role in the history of human life and the evolution of human civilization. Today, due to extensive communication networks, the role of the road has diminished as a communication factor, but roads have always played the role of the vital element of human civilization. Some of the roads, such as the Iranian Road and the Silk Road, have a global reputation and some of them, like the Persian Gulf, are of great importance to their region. The Royal Road ${ }^{1}$ and the Silk Road ${ }^{2}$ are among the most important communication hubs between Iran and the countries of the West and the East and have had a great impact on the important events in Iran.

One of the branches of the Silk Road in Iran is the dry land in the Damghan ${ }^{3}-K_{0 o m e s h}{ }^{4}$ region to the Astarabad or the Qozloq Route, which has played a significant role in the transplantation between the region of Astarabad

\footnotetext{
${ }^{1}$ The great ancient Iranian road, which began in Babylon, and went through the bottlenecks of Zagros, Kermanshahan and Ekbatan (Hamadan), from there went to Ray and continued along the south of Alborz to Balkh (bacteria).

${ }^{2}$ The road to the "East and West" or the Silk Road of China began with the passing of several large countries, the most important bridge between the peoples and nations of the past. This road entered Iran in Sarakhs and from Sarakhs to Neishabur and from there to Ray. Then it turned into two branches in Qazvin, one of the Khoi border and the other on the border of Kermanshah withdrew from Iran and continued along the edges of the Euphrates and the Mediterranean. Shahrud was one of the places to rest between Neishabur and Ray and some of Shahrud's roads to Gorgan were called "Silk Gate". It is likely that the name of the Silk Road was first used by Ferdinand von Riestedtfen, a German scientist and geographer, in the middle of the nineteenth century.

3 A group believes that Damghan's name was originally "Ten Moghan", that is, where the Zoroastrian religion's leaders (Moghs) were once residing there. In the ancient period of the city, there were a hundred caverns in this area, which has different views about the exact location. Mostly believed that the location of this city was in the southwest of Damghan, and is considered by some as Qomes. The city of Saddarvazeh was around $200 \mathrm{BC}$ in the capital of the Parthians. The Greeks have called the city Hecateam Police. They used this name for cities with more than four gates. Among the historical monuments of Damghan is the mosque of Tarikhaneh (the symbol of the city of Damghan), the Pire Alamdar altar porch and the mosque, and one of the most interesting desert paths in Iran is the road going from Damghan to the south, ie Moaleman and Jandag.

${ }^{4}$ In the current region of Amiriyeh
} 
and Shahrud and Damghan from the distant past5. This route, after crossing Shahrud, Qaleh Now, Mojen, Tash, Shahkouh, Saray Aliabad, Qozloq and Garmab Dasht arrives at AAstarabad and Gorgan and then continued to Khwarazm, Bukhara, Samarkand and Central Asia (Matofi, 2010: 513). Unfortunately, despite the importance of this route, there is less information available about its importance in the available resources, especially in the Safavid course, and there is no complete research in this regard. In this article, the Qozloq Route is described in accordance some Iranian and foreign historians.

\section{The Importance of the Route in the Safavid Course}

The Safavid course (1907-1135 AH) is one of the most important courses of Iranian history, especially in the construction of roads and commercial vendors. During this course, roads, bridges and caravansaries were built that created a new development in Iran's foreign and domestic business. The Safavid course is called "golden age of tourists" for many European tourists came to visit Iran (Bayat, 1988: 132).

In the same course, Europeans formally and diplomaticlly entered Iran. With the arrival of Anthony Jenkinson in Iran through the Caspian Sea in 964 AH (1557 AD), Europeans obtained information for the establishment of a commercial relationship between Britain and Iran. In 960 AH (1553 AD) Richard John chenslr, with the permission of the Russian Tsar, formed a Russian-English joint venture called "Moskowi Company". The company was active in Armenia, AAstarabad and around the coast of the Caspian Sea (Taheri, 1975: 28-30).

Many domestic and foreign travelogues emphasized on the significance of this route in the Safavid course. In the Melkonov travelogue reads that since the Safavid Shah Abbas considered the peoples' movement, he built roads and streets, one of which is a route that begins in Azerbaijan, and after passing Gazgar, Anzali, Babol and Astarabad to Gorgan. Another branch of the mountain went to Shahrud, Bastam and Mashhad, and another branch of the Alborz Mountains went to Aliabad and Khorramabad. He regretted that the routes built by Shaab Abbas with a caravanserai in two parasang intervals for the well-being of people are all destroyed (Ezud Dollah and Melkonov, 1984: 98).

Melkonov wrote about the commercial importance of this route in a trade with Russia: "The Caspian shores are the mainstay of Russian trade because they have opened roads close to Khiva and India. Referring to Hanoi's6 remarks, he continues: The way for Russian acquaintance with the northern parts of Iran was opened in 1556. It was when the first sailing vessel entered the Caspian Sea. At that time Gilan and Mazandaran were captured by the Ottomans and they did not have a good view of trading with foreigners, and they had only commercial relations with the Caucasus, including Sharwanat. The merchants of these places were also English, and therefore the Russian trade did not prosper (Borjian, 2008: 101).

At the time of Peter the Great, although the Caspian coast was in the hands of Russia, Russian businessmen did not know much about that place, and John Allton7 a British businessman serving Peter the Great operated there. He succeeded in establishing good relations between Iran and Russia and boosting trade between the two countries, but failed to continue due to internal and external differences in business expansion. Following him, Kakariyev and Tornau managed to somewhat expand trade by building commercial spaces in Shahrud, Bastam and Astarabad (Ezud Dollah and Melkonov, 1984: 102).

The importance of the route, and in particular the Qozloq Route in the Safavid course, is received more or less from the available sources. The war in Kandahar during the reign of Shah Abbas II was among the important events of the Safavid course in which the Qozloq Route is mentioned (1057-1077 AH). Although the Qizilbashs finally wins in that war, the Kandahar siege continued for six months. The long siege caused shortages of food and hunger, and Shahab Abbas ordered to bring 15,000 tons of grain from Shiraz, Astarabad, Kerman, Ray and Shahriar to Kandahar and distribute them to people. After this event, Shah Abbas II came to Astarabad in the

\footnotetext{
${ }^{5}$ Shahrood or, as some indigenous people say, the "small continent" and "desert bride" are one of the areas that are located on the path of pilgrims Ali bin Musal Reza and $400 \mathrm{~km}$ from the capital, from the north to the provinces of Mazandaran and Golestan, from the south to the central desert and the provinces of Yazd and Isfahan and from the west to Damghan and from the east to the city of Miami and the main road of Tehran to Mashhad. The dating of Shahrood is attributed to the Ilkhan period. According to some architectural and archaeological evidence inside and outside the city, as well as some historical texts, the passage of carriages and caravans passing from the western highway to the eastern (Silk Road) passes through Shahrud, and the presence of Chapar Khan and the caravanserai in this province turned it into one of the major unilateral centers in the region.

${ }^{6}$ Jonas Hanoi, a well-known British businessman who traveled to Iran and became familiar with the northern parts of Iran (Ezud Dollah and Melkonov, 1984: 101).

${ }^{7}$ Captain John Alton was an Admiral and merchant of English who traveled to Rasht through the Volga and Caspian Sea (1739), and in the absence of Nader, Reza Gholami Mirza, received a favorable offer for the Moscow Company. At that time, the capital of Iran was Mashhad, and Alton wanted to move to northern Iran, away from the British factories in Bandar Abbas and Isfahan. He later disagreed with Russia and helped Nader in the war in Georgia... (Encyclopedia of Gholam Hossein Mosaheb... According to Ezud Dollah and Melkonov, 1984:101).
} 
year $1064 \mathrm{AH}$ through Chaman, Bastam and Qozloq and after a while he stayed in this city then left to Farahahad and then Khorasan (MirKhwand, 1959: 473-464).

Another event pointing to the importance of the route happened during the reign of King Solomon, the successor and son of Shah Abbas II. At that time, Turkmen tribes headed by Adina united and attacked over 60,000 riders in Astarabad, then went to Damghan and Semnan. Shah Solomon sent Kalba Ali Khan Shamloo to suppress Adina, and Adina, who went to the Gorgan River, along a river dug a large ditch, and trenched there with armies. Kalba Ali Khan entered Astarabad and then went to Gorgan via Siyab route. In that conflict, Gulich Khan, the ruling ruler of Strabad, and Jamshid Khan, the governor of Bastam, were commanders of the Kalba Ali Khan, who consisted of Qajar, Afshar, Astarabad, Katoul, Kaboydjama, Mazandaran, and Iraqi gunmen. In this bloody battle, Kalba Ali Khan was wounded, but eventually the Turkmens were defeated, and Adina was killed by a rider when he was escaping, and his head was taken to Kalba Ali Khan (Ibn Esfandiar Kateb, 1941).

The attention of foreigners to the regional routes of Gorgan is well known in one of the turbulent courses of Safavid rule, the time of the rule of Tahmasp II. In $1135 \mathrm{AH}$. The Ottoman troops declared war on Iran, Tahmasp II resorted to Russia and signed with them the contract of St. Petersburg. According to Article 2 of the treaty, the Russians were obliged to support Tahmasp II against the Afghans; instead they would hand over the Russians to Baku, Darband and the provinces of Astarabad, Mazandaran, and Gilan. The Russians sent their troops to the command of Shipov and Swimonov (navy commander) to capture the states, and after the capture of Rasht, Lavshev was assigned to the rule of Guilan. Shahtasmpos II, who was frightened by the actions of the Russians, sent Mohammad Gholli Saadlou to war with them, but did not succeed. The Russians were unsuccessful in trying to capture Astarabad. The Russian rivals, namely France, and in particular the Britian, had a strong desire to capture Astarabad, as the city was on the path to important trade routes. Terrestrialism with Russia in the terrestrial and seashore areas and the existence of two harbors and ports of Ashuradeh and Bandar-Gaz doubled the importance of this region. Access to the Shahrud -Astarabad has had a special privilege for the military forces movement for each of its rival powers. There were two routes between Astarabad and Shahrud; one of the villages of Ziarat, Shahkouh and Bastam, and the other from Qozloq, Shahkouh and Bastam to Shahrud. The victorious forces could access to Khorasan, Afghanistan and India. In spite of all the strife, the death of Peter the Great in 1145 AH. (1725 AD), settled down the conflicts and the Russians returned to their homeland (MirKhwand, 1959: 212).

Following the signing of a friendly agreement between Iran and Russia in 1732, (1145 AH), Tahmasp II, who was involved in the war with the Afghans, sought help from Fathali Khan Qajar, the then ruling governor of Astarabad. Fathali Khan was sent to Tehran to help him with a troop of Qajars, Turkmens, residents of Astarabad, Katoul and Greeley, and traveled to Tehran through Damghan and Semnan but the result was positive. Then he joined the Tahmasp II troops, who had left for Mazandaran. After that, they were equipping with Tahmasp II in Astarabad. Tahmasp II on 14 Shawwal 1139 AH transferred the government of Gorgan and Astarabad to Fathali Khan, and they themselves and his troops went to the "Chaman" of Chardah Kalateh. Fathali Khan Army also joined them some time later, and all went to Damghan. Nadrqoli Afshar (Nader Shah of the Future) also joined them on the way to Khabushan (Matofi, 1995: 212-215).

\section{Qozloq Route}

Astarabad route to Qozloq, Shahkouh, Tash and Shahrud after leaving the Fujärd gate in the south of the city of Astarabad passes Golam Bridge, Kheirat village, Tuskestan forest, Golsh baneh, Garmabdasht, Gachian, Qozloq caravansaries, Dima Lu, Sar Aliabad and Robat Sefid, Chaharbagh, Shahkouh, Tash, Mojen8, Qala i Naw, Bastam to Shahrud, and then Damghan and Khorasan. Although the roads of Olang, Abr, and Khosh yeylaq are also used by the locals in Shahrud as communication routes, but the roads have long been for the passage of caravans and migrants as a way of commerce (transportation of goods), a way of tourism (travel) and the pilgrimage route (going to Khorasan and Mashhad), as well as the gracefulness of the Alborz mountains, has been of great importance. This route is known as Tuskastan route, Shahkouh route, and Qozloq Route among the Gorganis, Shahrudis' and the local people, respectively.

Matofi (2005: 513 to 515) wrote about the old ways of Astarabad and the Qozloq Route: "There were several main and secondary routes in the province of Astarabad, which brought different parts of the state to Shahrud

\footnotetext{
${ }^{8}$ Mojen Shahrud, $35 \mathrm{~km}$ northwest of Shahrud, lies in the range of eastern Alborz Mountains and is limited to north and northwest of Golestan province and south and south-east of Shahrud. The city is located in a relatively large valley between the two rivers Peyhesar and Pishdeh and because of its location in the mountainous area, the city is deadlocked, and the only way of connecting it the route that connects Shahrud to Bastam. The existence of ruins and castles around the city and works of art and pottery that remain in the surrounding hills, as well as the existence of the two oldest trees of the Ursus, known in the region called Sur, indicates its historic date.
} 
and from there to Khorasan and Tehran."'Then, it refers to a number of ways that are:

A) The route from Astarabad to Qozloq, Shahkouh and Shahrud.

B) The route from Bandar Gaz to the Sadan, Shemushack, Sandoqposht and Jahannama

C) The route from Astarabad to Ziyarat, Chaharbagh, Shahkouh and Shahrud

D) The route from Katoul to Shahkouh and Shahrud.

E) Shah Fassand (the next Shapesand and the present Azadshahr) to the Minoodasht, Kohsaran, Chenash and Shahrud.

Robino described the Qozloq Route distance as part of the Abbasid road as follows: "From Astarabad to Shahrud, through the Qozloq mountain pass, through Nomel to Kheirat (1040 feet high), 10 miles, Goramdasht, Rabat Qozloq, Boland Sofale (height 5200 feet) 15 miles, Qozloq mountain pass peak (7200 feet), Chaharbagh (6700 feet) Ali-Abad's ruins (7300 feet), Jalin Barin mountain pass (8000 feet), Haft Cheshme 10 Miles, Qab-re Sefid, Kotal Vijmanno (9000 feet) Thash (7,700 feet), 9 miles, Robat Tajar, Chalateh (5510 feet), Shahrud (5000), 19 miles and in total 63 Miles" (Robino, 1957: 126-127).

Mohammad Ali Qurkhanchi, "known as the Solate-e Nezam", wrote about Tehran to Shahrud route from Astarabad, which is also part of the Qozloq route: "From Tehran to Astarabad from the Shahroud line, counted the number of resting places is fourteen resting place and eighty two parasang9: Khatun Abad or Sharif Abad, Ivan Kiev, Gheshlag, Dehnamak, Lasgerd, Semnan, Ahvan, Ghosheh, Damghan, Deh Mullah, Shahrud, Tash and Qozloq" (Qurkhanchi, 1981: 65). He describes the resting places and the route in "Nokhbato Al-seifiye" introducing the Damghan as: "Ali Dadghan spring is three miles south of Damghan and extends along the route to the northwest beside the river that goes south along to Damghan. In the west of the river is a tall mountain that says that Landehur bin Sa'ad is buried at the top of that mountain and on its "anterior" mountain is another cone-shaped mountain, called the Shahdar Mountain, and on the eastern side of the river, is a large black mountain, it is Mansoor Mountain or Mount Mansarihah. "There are farms and villages and near the route exist a high mountain, with a fort with the tower and the wall at the top, since the time of its predecessor, and that mountain, called Mehr and Takvar...” (Ibid, 72). The route from Damghan to Deh Mulla is six parasang eastward and twenty degrees northward. After passing through the old ruins of Damghan, it reaches the garden of Zia al-Dawlah, from which to Deh Mulla the route is smooth and paved, and to Mehmandost which is three parasangs away from Damghan, there are many villages around the road. "There is a distance of half a mile to the road."

Deh Mulla is a rich village with gardens and well-known fruits, and has a caravanserai of Shah Abbasi and a coffee shop. From there you can also go to Astarabad and the distance is one resting place less.

From Deh Mulla to Shahrud is four parasangs and the path goes to the northward. In two parasangs to the right, there are low mountains that are connected to the desert, and on the other side there are many farms and. After Deh Mulla there is only a coffee shop just two parasangs away. Shahrud is a prestigious and "merchant" city where domestic and foreign businessmen are engaged in business. There are numerous markets and caravansaries and businessmen, with a lot of fruit and baths, and new quality caravansaries made for the travelers. "The Shahrud rule is located in Bastam, and in Shahrud there is no governmental building (Ibid, 74).

Qurkhanchi about the continuation of the route and the resting places on the route says that Bastam is located between two mountain ranges and its population and villages are less than that of Shahrud. "There is an old fortress that is the place where the rulers sit." The Shahvar Mountain, known as the "Jabal", is located in Bastam, and some of the pleasant hobs are on the slopes of this mountain. The villages of Khoraghan, Moghan, Abar Sijj and snowy mountains are visible on this side and from Bastam. From Shahrud to Tash is six parasangs away and the road to the shrine of the deceased Prince Jahansouz Mirza, is a smooth street for carts full of trees. The shrine of the deceased Prince Jahansouz Mirza is full of orchards and fruit trees and a mansion with the water of the spring and the river, and is one parasang to the city. From this hrine, the road to the west and on both sides of the road, about a parasang away, and in some places less, leads to the mountains and hills, and in this way, some rock formations above the hills and mountains are still exist. Three parasangs to Mohammad Abad is a coffee shop and a caravanserai underneath the newly built road and a coffee house with a farm next to the road, there everywhere is rocky and sandy. The hill climbs up a rocky and dusty altitude. From there, there are two parasangs to Tash and road is everywhere inclined to the north-east and the two sides of the road leading to the mountains. The down road is the river, and in parasang is a farm, a village known as Grava; and the river and the

${ }^{9}$ Each parasang is about $22 \mathrm{KM}$. 
waters are known as Dane Doab. Tash is part of Shahko and is a combination of upper and lower Tash. It's about six parasangs to Qozloq and one parasang to the mountain pass and Jillin and Balin Kotal and around the route are the hills and mountains. This Kotal is very jagged and has stones, and it is difficult to walk in the summer, let alone the winter... (Ibid, 74-75).

According to Qurkhanchi, the height of the Qozloq Kotal is estimated at $228 \mathrm{~m}$, and the route continues. The road is also downhill to reach the Haji Ali Caravanserai, and there is no village on the route and the route is gradually intends to the west, on both sides of the road, there are mountain and river. The route is fairly flat road leading to "Dj Mino" mountain pass one parasang passed through the Haji Ali Caravanserai. This Kotal is not so tumultuous and its "distortion" is less and it is not paved. The road is the left to the valley. The weather here is always cloudy and windy. Even in the mid-summer it still is a danger to man. From Kotal to Rabat Sefid, it is one parasang and runs all the way down the slopes of the mountain. After passing through the Robat Sefid the path continues on the slope leading to the first passage of the Qozloq (Ibid, 76).

\section{Caravanseries on the Roads}

According to archaeological findings and historical documents, the Qozloq area seems to have enjoyed a certain boom in the past and through the transport and tourism carriages of that area and it is important for the establishment of the connection between the plain of Gorgan and the old main roads located in the Central Plateau and the Great Khorasan Road. There are many Caravanseries in the resting places on routes that now only some of them are ruins and some have been completely destroyed.

Qozloq Caravanseri is about $35 \mathrm{~km}$ southwest of Gorgan city and among lush forests and lush and fertile slopes, along the road of Gorgan - Chaharbagh and Shahkouh, there are works of caravanserai which is called Qozloq Caravanserai. The caravanserai, located $3554 \mathrm{~km}$ long and 5136 latitudes, is a reminder of the name of the road and the region of Qozloq who has played a significant role in the history of Gorgan.

Architecture of Qozloq Caravanserai with regard to the type of performance, drawing and construction style, is one of the caravansaries of the mountainous interiors, which is comparable to the "Shabli" caravanserai in the Shabli mountain pass of Azerbaijan, the "Imamzadeh Hashem" caravanserai in Imamzadeh Hashem mountain pass on the road of Haraz and the Gadouk Caravanserai located on the Firoozkooh Road, which was built in the Safavid dynasty and was restored and used in the following courses, especially during the Qajar course (Malcolm, 2000).

Qozloq caravanserai and all the caravansaries on the old road of Shahkouh-Astarabad (Deyme Lu, Rabat Sefid, and Ali Abad Road) have been constructed for the sake of the well-being of tired caravans and passengers (Omrani Rekawandi, 1999).

The caravanserai's interior was made up of 12 small chambers that were positioned in a quill line in a row of $2 \mathrm{x}$ $2.5 \times 2.5$ meters opposite each other. The spaces between each chamber are fitted with grips that divide the interior while storing the ceiling. Within each of the chambers, a place was made to light the fire to provide the heat of the interior of the chambers during the cold season (Ibid).

What contributes to the strength and durability of the Qozloq caravanserai is the thickness of the walls and the foundation $(120 \mathrm{~cm})$ and the type of construction materials (river crests and Sarooj mortar), which has prevented the rolling down of the caravanserai. In order to prevent the penetration and absorption of water from the fall of atmospheric precipitation, the dome ceilings are covered with a mixture of gypsum, lime, soil and ash, and after being sloped, it is lined with mortar and lime (Ibn Hawkhel, 1966).

\section{Robat Sefid Caravanserai}

At $49 \mathrm{~km}$ from Gorgan city and along the road of Tuscistan to Shahrud (Qozloq Route), there is another Caravanserai remains called Rabat Sefid Caravanserai or Saralai Abad. This Caravanserai is located $55 \mathrm{~km}$ east of the Chahar Bagh village, south of Astarabad, central part of Gorgan city. The Robat Sefid Caravanserai is one of the main resting places of the Astarabad to Shahrud route, which continues to link to the Great Khorasan Road. The construction of this rectangular caravanserai, whose length is about 24 meters and a width of 22 meters, has been completed in the Safavid course. Its internal structure consists of several symmetrical cellars with semi-dome roofs (Matofi, 2010: 564-565).

The main building material is obtained from the natural habitat materials, including mountain and river rocks, a few bricks, sandstone, limestone, gypsum and wood (for openings and beams). Robat Sefid Caravanserai has been a valuable place to cater to many diverse passersby and prominent personalities. As in 1963, the English agent in Astarabad wrote: “... The new ruler of Astarabad (Muid al-Dawlah) moved from Shahrud and met with Amir Azam (the son of the Great Amir Azam) and came to Tash. Tomorrow they were in the Rabat Sefid, and the 
next day they entered the desert of Kheirat in Astarabad" (Ibid, 564).

According to some historians, the Rabat Sefid caravanserai has had many facilities and prosperity, as described by Qurkhanchi (1981: 76) The Rabat Sefid caravanserai is made of stone, with coffee shop and barn, which is better than anywhere in the winter.

Next to the caravanserai, there is a cool water spring that is also very good in the warmest season of the year. The caravanserai is covered with its three rooms facing the entrance door at the end of the building. It has an indoor porch, similar to Rabat Anushirovani Ahuan, is of course smaller, for entry. It seems that there were four rooms on the sides of the entrance hall. Niches and many heaters have been embedded in the rooms and walls of the caravanserai.

\section{Daymelu Caravanserai}

Daymelu Caravanserai is one of the Safavid course works located on the western side of the mountain road of Gorgan to Shahkouh in between the Qozloq Caravanserai (north) and the Rabat Sefid Caravanserai (South). The location of this Caravanserai is in the central part of the Shahkouh village in the central part of the county. During the Safavid course, it was used by caravans when the crowded Qozloq Caravanserai and Rabat Sefid Caravanserai could not host more.

This work was registered on May 31, 2010 with the registration number 8798 as one of the national monuments of Iran.

\section{Conclusion}

The Qozloq Route (Astarabad to Shahrud) has been expanded and refurbished in the Safavid course and has enjoyed a great boom. This route has become an important channel of communication between nations and different people, which, while trading commercial goods, has spread the culture of different lands in the region and affected the political, economic, social and cultural life of the people. It has had a lot. Unfortunately, despite the great value of this route for the region, there are not many sources that reveal its importance in the Safavid course, and more can be seen from the travel logs and reports available in the Qajar course that indicate Qozloq Route for many reasons have been significant for the Safavid fate:

- Culturally and ritually: The collision of nations and tribes through this route has led to the dissemination of Iranian culture and religion, especially the spiritual influence of the Safavids.

- Strategically and militarily: this was the gateway to Russia, Khorasan, Afghanistan and India, as well as many the route for arms transportation and supplies of arms and ammunition. It was also used to suppress rebellions and disobedience.

- Defense equipment and preparedness: Because this route has also been linked to neighboring countries, such as Russia, it is a good route to buy and carry weapons such as cannon balls and guns and other weapons from these countries.

- Trading and shipping and transportation of goods: the prosperity and life of important commercial ports such Asuradeh, Bandar Gaz and Bandar Gomish Tape (Gomishan) and the old and large bazaars of Astarabad, the old market and the market of Nalbandan depended on this route. The abundance of domestic and foreign commodities such as silk, garden products and legumes, and livestock and industrial products... have been traded and transported on this route. The prosperity of foreign trade, especially with Russia and the UK, has been possible through this route. From the point of view of Russia and the United Kingdom, and even France and Germany, it has been of strategic and commercial importance and attracted the attention of the Safavid government.

- Pilgrimage and information exchange: Many tourists, and caravans of foreign and domestic tourists traveled through this route, as well as pilgrims, and letter carrierstravelled the same route across the country, especially to northern Iran and Khorasan region.

- Entrepreneurship and Monetization: The survival of caravansaries along the route depended on the existence and mobility of this road. Many people were fortunate enough to have this way of life, and many products were sold to the caravans along the way. Caravans, locksmiths, leasers, kayaks, horses, mules and camels... Those who used this way naturally favored the Safavid rule.

- Meet the Elders and Exchange the Revenues: The caravansas were places to meet the heads and exchange gifts and ransom of the elders of the states.

- Development: speeding up affairs and unlocking the gates of global progress requires the development of 
advanced communication networks, Qozloq Route has been well suited for this goal.

\section{References}

Bayat, A. (1988). General Geography and History of Iran. Tehran: Amir Kabir.

Borjian, H. (2008). The Extinct Language of Gurgan: Its Sources and Origins. Journal- Americanoriental Society, $128(4)$.

Ezud Dollah and Melkonov. (1984). Iranian and Russian travelogue: Northern regions of Iran. Translation by Mohammad Golbon and Faramarz Talebi, Tehran: Donyaye Ketab.

Ibn Esfandiar Kateb, Baha'ddin Muhammad ibn Hassan. (1941). Tabarestan History. Corrected by: Abbas Iqbal. Tehran: Kaleh Khavar.

Ibn Hawkhel. (1966). Face of the earth. Translation by Dr. Jafar Shoar, Tehran: Culture Foundation.

Malcolm, J. (2000). Full History of Iran. Translated by Mirza Ismail Heyrat. Tehran: Afsoon.

Matofi, A. (1995). History of Culture and Literature of Gorgan and AAstarabad (A Brief History of the Literature of Iran, Gorgan and AAstarabad). Gorgan: Padideh.

Matofi, A. (2005). AAstarabad and Gorgan (in the context of Iranian history). Gorgan Author, Jalali.

Matofi, A. (2010). History and social background of Sarkhon Kalateh, Ziyarat and Shahkouh. Gorgan: Makhtumqholi Faraghi.

MirKhwand, Mohammad Ibn Khwandashah. (1959). Rawżat aș-șafā. Tehran: Khayyam.

Omrani Rekawandi, H. (1999). Qozloq caravanserai study and organizing report. Gorgan: Cultural Heritage of Golestan Province.

Qurkhanchi, M. A. (1981). Nukhba e Saifiyya: Dar Tarikh o Jughrafiya e Astarabad.

Robino, H. L. (1957). Mazandaran and Astarabad. Translation by Gholamali Vahid Mazandarani, Tehran: Scientific and Cultural.

Taheri Abulghasem. (1975). The history of British and Iranian commercial and political relations from the time of the Mongol rule until the end of the Qajar course. Tehran: National Art Association.

\section{Appendix 1.}

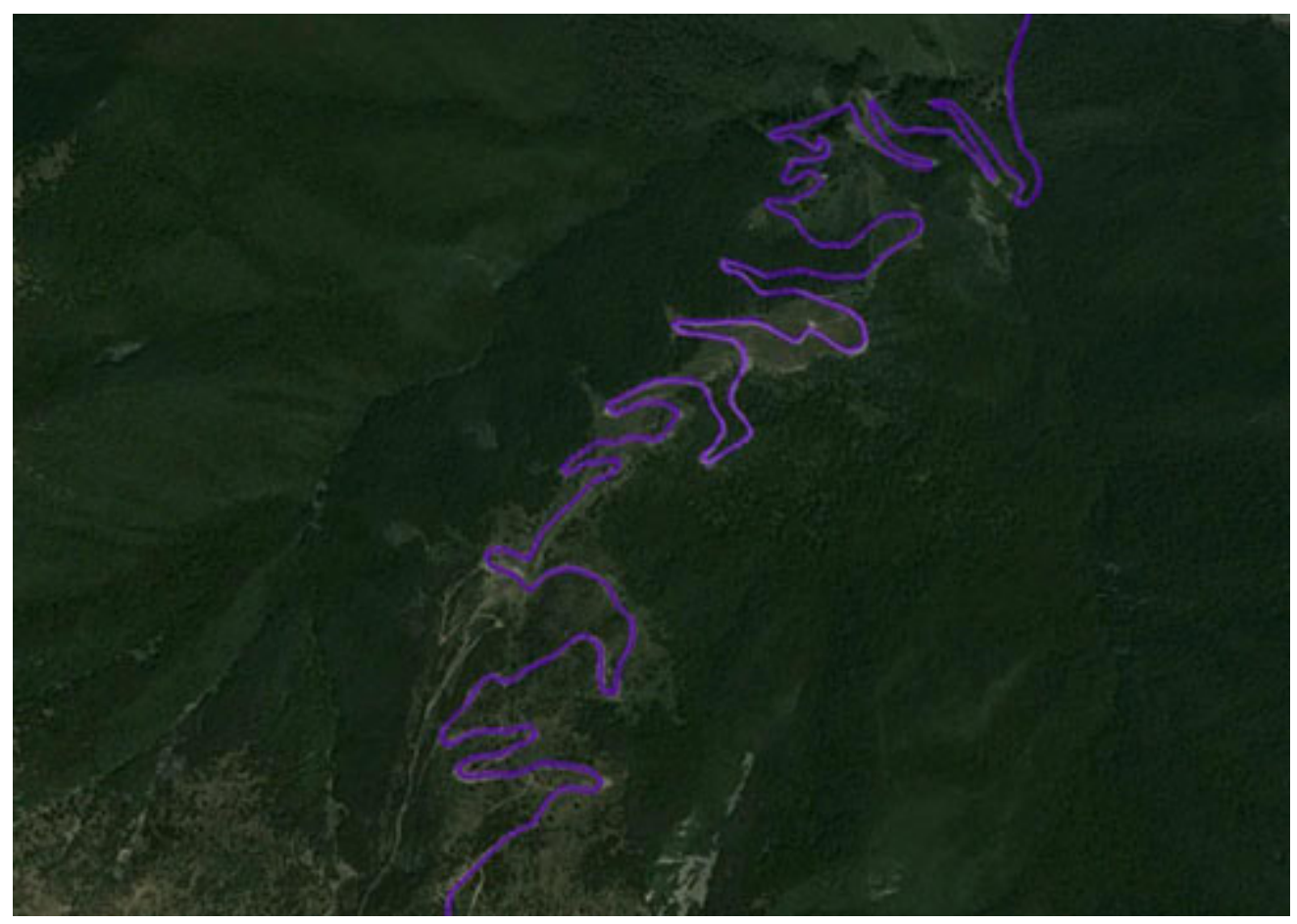

Figure 1. Aerial map of Qozloq Route on Tuskastan forest 


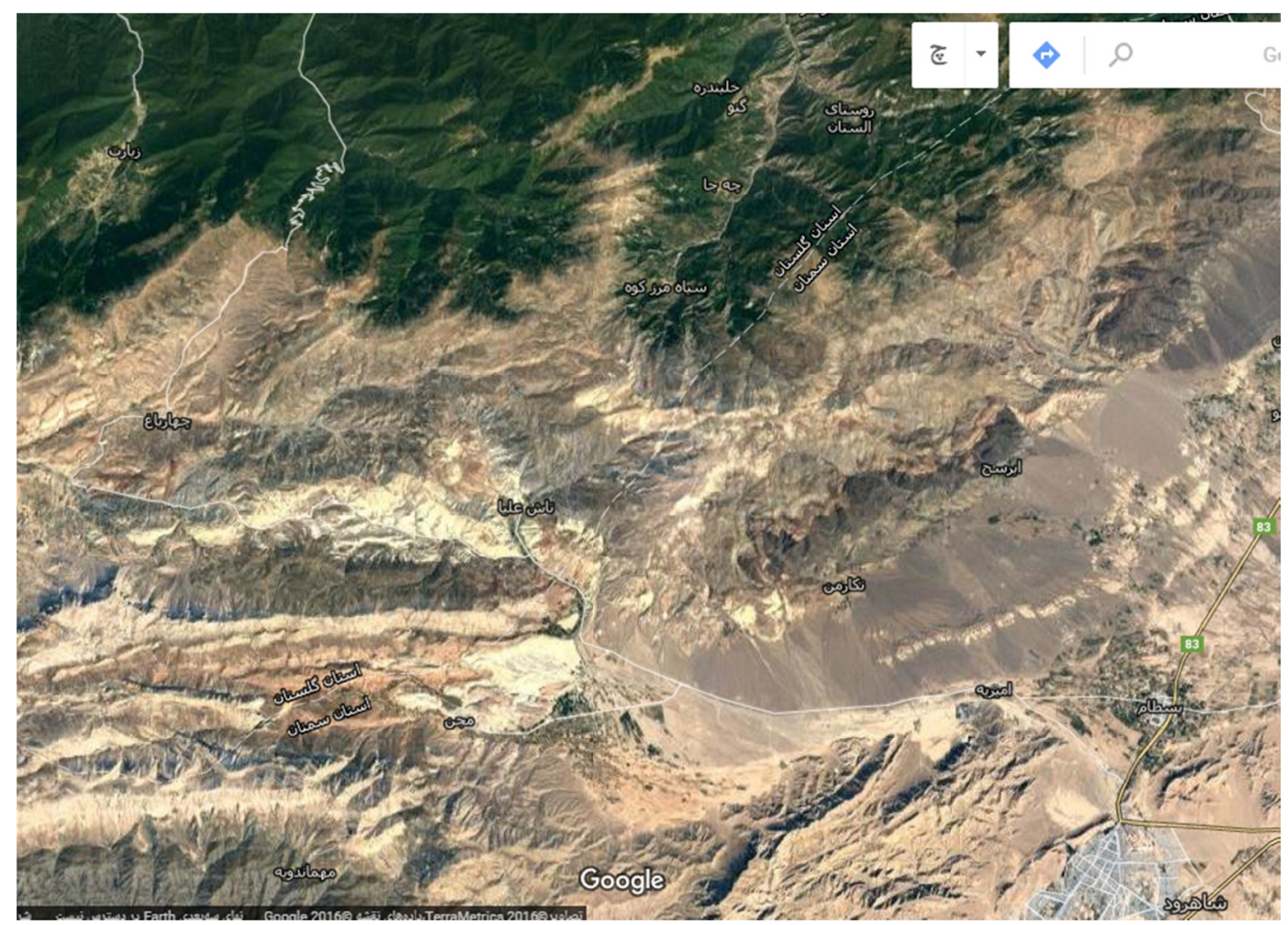

Figure 2. Aerial map of the current Qozloq Route (from Shahrud to Tuskastan)

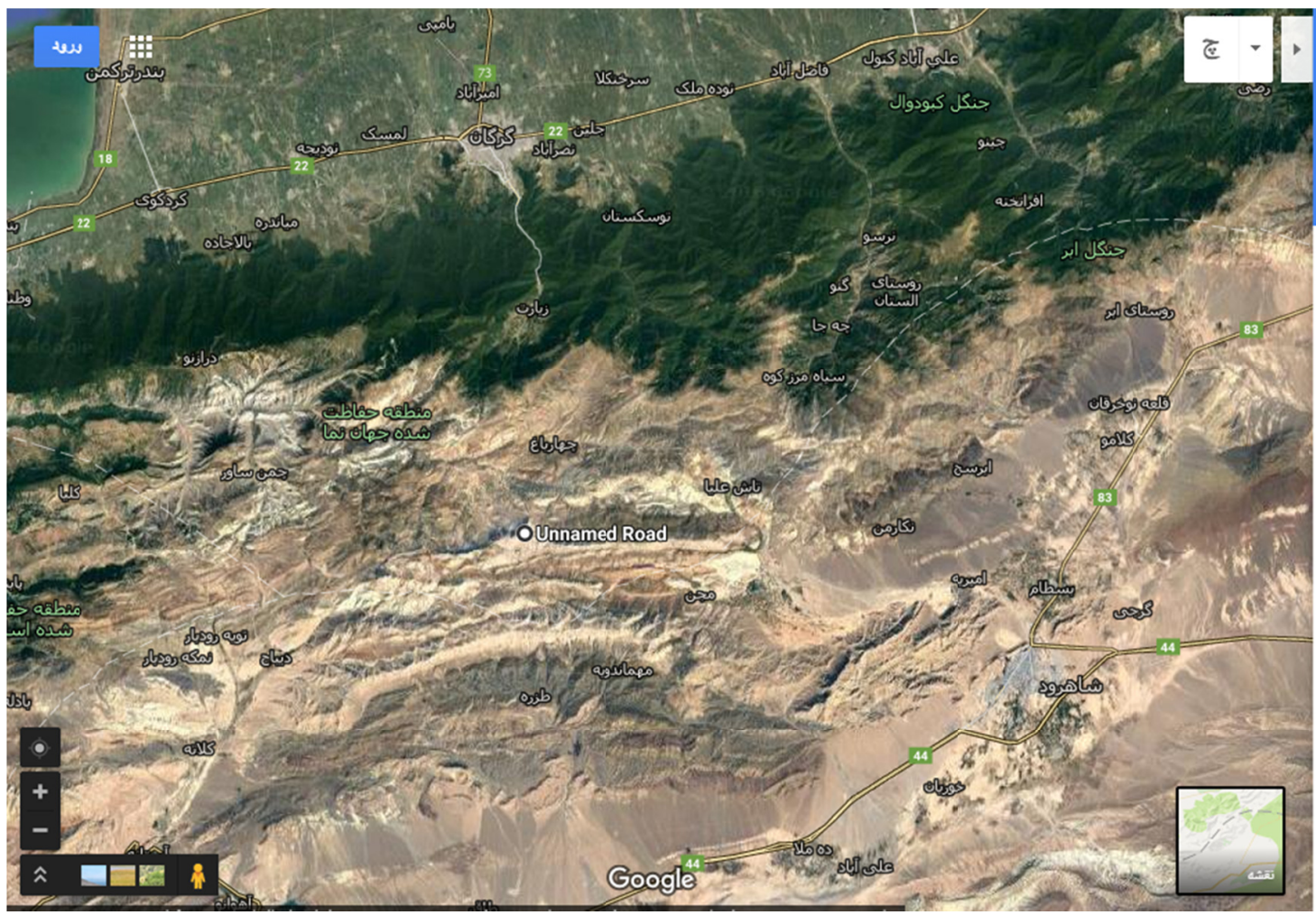

Figure 3. Aerial map of the current Qozloq Route (from Shahrud to Gorgan) 


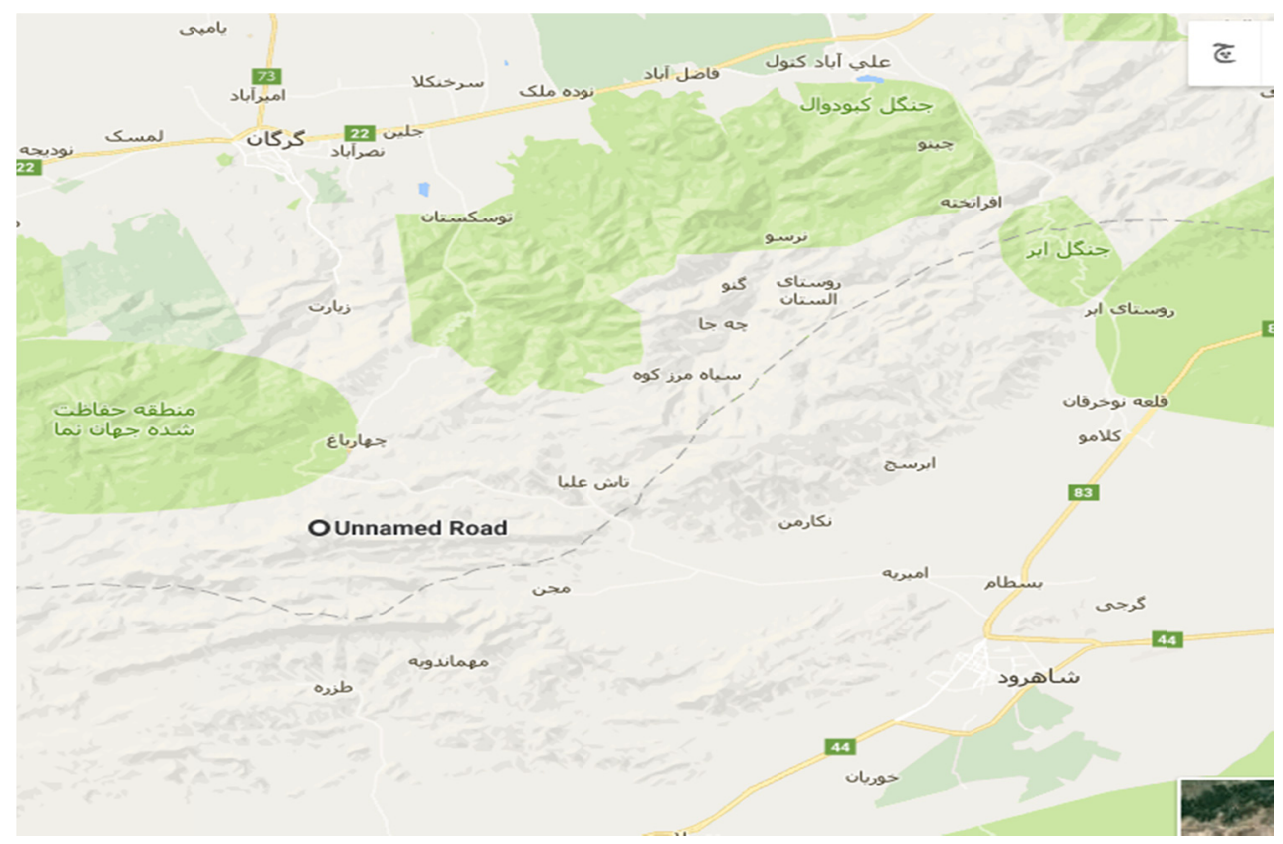

Figure 4. The current Qozloq Route (from Shahrud to Gorgan)

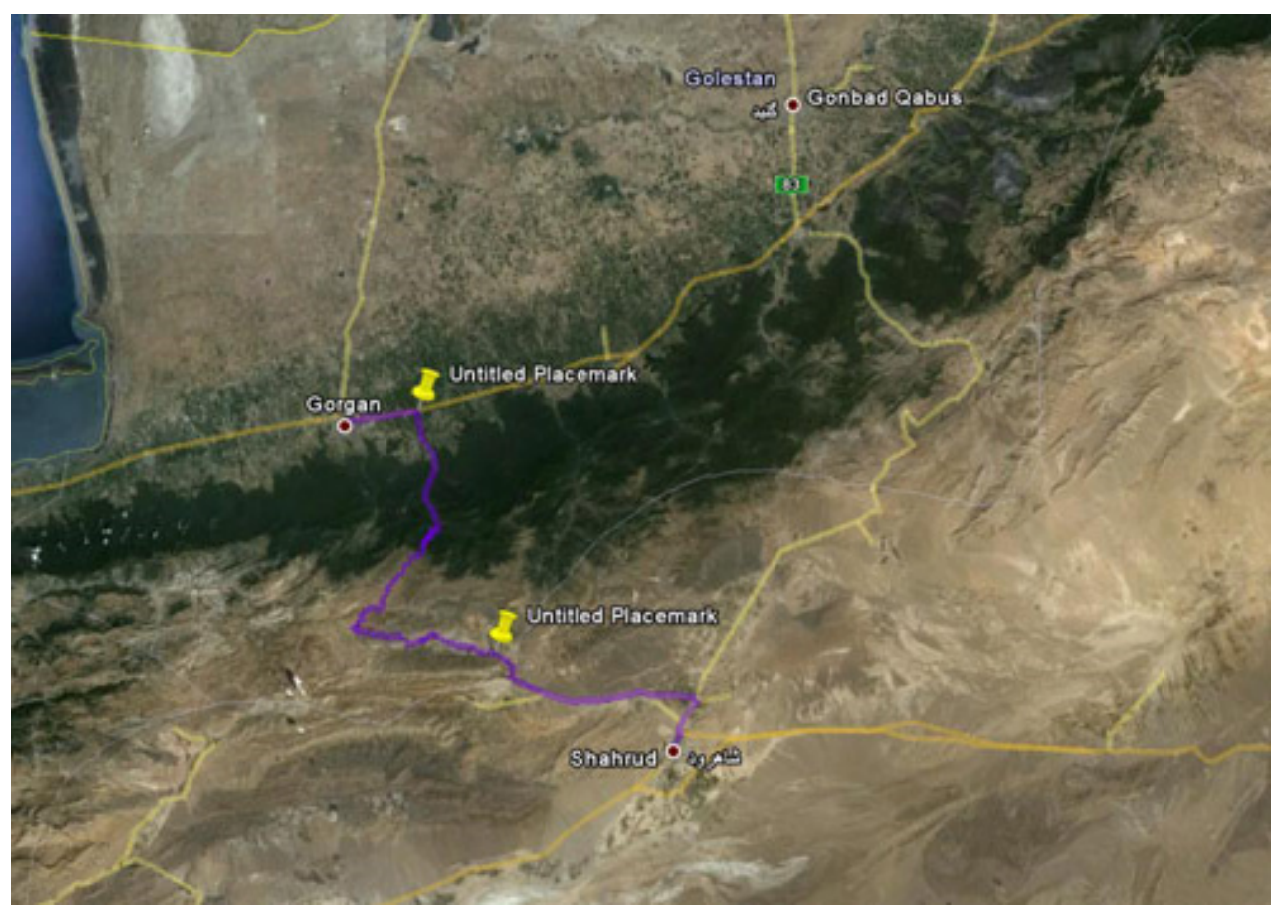

Figure 5. Two routes from Shahrud to AAstarabad (old and new) 


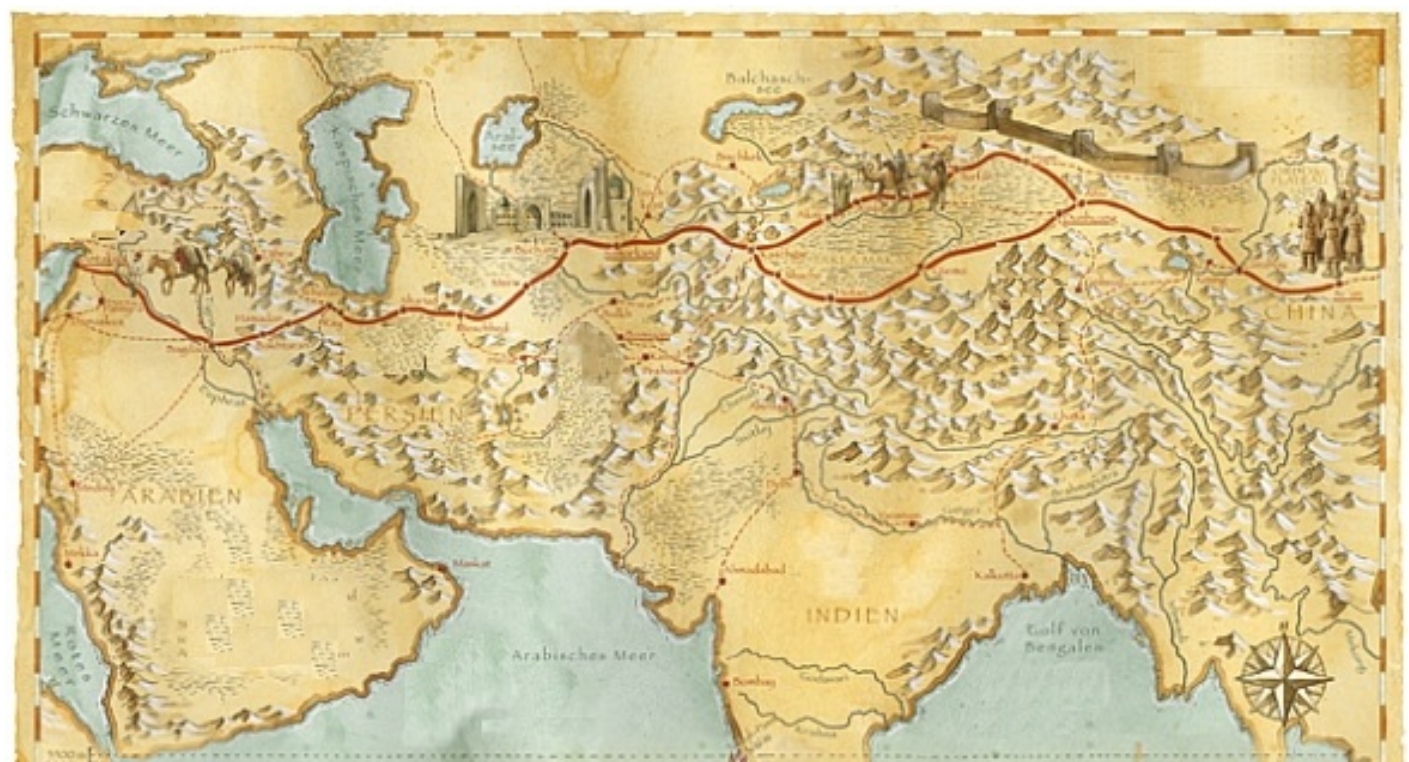

Figure 6. Sillk road

\section{Copyrights}

Copyright for this article is retained by the author(s), with first publication rights granted to the journal.

This is an open-access article distributed under the terms and conditions of the Creative Commons Attribution license (http://creativecommons.org/licenses/by/4.0/). 